\title{
Synaptic-Type Acetylcholine Receptors Raise Intracellular Calcium Levels in Neurons by Two Mechanisms
}

\author{
Margaret M. Rathouz and Darwin K. Berg \\ Department of Biology, 0357, University of California, San Diego, La Jolla, California 92093-0357
}

Nicotinic acetylcholine receptors (AChRs) located in the postsynaptic membrane on neurons are responsible for mediating fast, excitatory synaptic transmission. If synaptic AChRs are also highly permeable to calcium as reported recently for several kinds of neuronal AChRs, the synaptic receptors could regulate calcium-dependent events in the neurons in concert with normal transmission. Chick ciliary ganglion neurons have two classes of AChRs, one located predominantly in the synaptic membrane and responsible for synaptic signaling through the ganglion and the other located almost exclusively in nonsynaptic membrane and having no known function. The nonsynaptic receptors can readily elevate intracellular calcium concentrations. The experiments reported here indicate that synaptic-type receptors can raise intracelluiar calcium levels to the same extent as the nonsynaptic receptors and that they do so not only by being permeable to calcium themselves but also by activating voltage-dependent calcium channels (VDCCs). Currents of equivalent amplitude are obtained through the synaptic-type receptors when neurons are bathed in solutions containing either sodium or calcium as the sole extracellular cation. Measuring the effect of ion substitutions on the reversal potential of the receptors and applying the GoldmanHodgkin-Katz constant field equation indicates the receptors are at least as permeable to calcium as to sodium. When neurons are loaded with the calcium-sensitive dye fluo-3 and challenged with nicotine, both the synaptic-type and nonsynaptic AChRs substantially elevate intracellular calcium levels under physiological conditions, and do so largely by activating VDCCs. Confirmation that synaptic-type AChRs can elevate intracellular calcium levels in the absence of contributions from VDCCs was obtained from voltage-clamp experiments on neurons loaded with fluo-3. The fluorescence signals indicate that the nicotine-induced calcium increases in neurons voltage clamped at rest are nearly as great as those induced in the same neurons when VDCCs are maximally activated by a voltage step. Calcium flux through AChRs may be particularly important for mediating local changes in calcium concentrations near the plasma

\footnotetext{
Received Nov. 2, 1993; revised May 11, 1994; accepted May 12, 1994.

We thank V. Dionne, S. Vijayaraghavan, N. Spitzer, and Z.-w. Zhang for helpful suggestions during the course of this work, and N. Spitzer for reviewing the manuscript. Grant support was provided by the National Institutes of Health (Grants R01 NS12601 and P01 NS25916) and the California Tobacco-Related Disease Research Program.

Correspondence should be addressed to Darwin K. Berg, Department of Biology, 0357, University of California, San Diego, 9500 Gilman Drive, La Jolla, CA 92093-0357

Copyright (C) 1994 Society for Neuroscience $0270-6474 / 94 / 146935-11 \$ 05.00 / 0$
}

membrane, which, in turn, could regulate specific membrane-associated calcium-dependent events.

[Key words: nicotinic receptors, neuronal ACh receptors, calcium permeability, ciliary ganglion neurons]

Molecular mechanisms that alter calcium levels in neurons have the potential for important regulatory consequences. One mechanism for altering calcium levels is provided by ligand-gated ion channels having a high permeability to calcium. The most prominent example is that of glutamate receptors responding to NMDA. By virtue of their calcium permeability (MacDermott et al., 1986; Mayer and Westbrook, 1987), NMDA receptors are thought to mediate phenomena as diverse as longterm potentiation (Collingridge et al., 1983; Malenka et al., 1988), development of retinotectal maps (Cline and Constantine-Paton, 1989), and cytotoxicity (Choi ct al., 1988).

Nicotinic acetylcholine receptors (AChRs) represent an abundant class of ligand-gated ion channels in the nervous system (for review see Sargent, 1993). Several species of neuronal AChRs have been shown to be equally permeable to calcium and sodium, having approximately five times the relative calcium permeability of vertebrate muscle AChRs (Fieber and Adams, 1991; Mulle et al., 1993; Sands and Barish, 1992; Vernino et al., 1992). The highest calcium: sodium permeability ratio has been reported for receptors resulting from expression of the AChR $\alpha 7$ gene in Xenopus oocytes. For these presumed $\alpha 7$ homomers, the ratio has been estimated to be in the range of $10: 1$ or $20: 1$ (Bertrand et al., 1993; Seguela et al., 1993), values similar to those reported for NMDA receptors.

Chick ciliary ganglion neurons have two classes of AChRs. One class is largely synaptic in location, binds the monoclonal antibody mAb 35, and is responsible for chemical synaptic transmission through the ganglion (Ravdin and Berg, 1979; Jacob et al., 1984; Loring et al., 1984; Halvorsen and Berg, 1987; Loring and Zigmond, 1987). As a population the receptors, referred to here as mAb 35-AChRs, contain the $\alpha 3, \beta 4$, and $\alpha 5$ gene products (Vernallis et al., 1993). The neurons also contain a second class of AChRs that are predominantly nonsynaptic in location, bind $\alpha$-bungarotoxin ( $\alpha \mathrm{Bgt}$ ), and are 5-10 times more abundant than mAb 35-AChRs (Jacob and Berg, 1983; Loring et al., 1985). The receptors, referred to here as $\alpha \mathrm{Bgt}-$ AChRs, contain $\alpha 7$ subunits but none of the other known neuronal AChR gene products (Vernallis et al., 1993). Recently it has been shown that native $\alpha \mathrm{Bgt}-\mathrm{AChRs}$ function as ligandgated ion channels and can elevate intracellular calcium levels in the neurons (Vijayaraghavan et al., 1992; Zhang et al., 1994).

We report here that synaptic-type AChRs on ciliary ganglion neurons are highly permeablc to calcium, being more like other neuronal AChRs in this respect than like synaptic AChRs in 
muscle. Moreover, the receptors elevate intracellular calcium in the neurons under physiological conditions to the same extent as the more abundant nonsynaptic $\alpha$ Bgt-AChRs, indicating that the same neurons can express and maintain at least two classes of nicotinic receptors with this feature. Both classes of AChRs rely heavily on activation of VDCCs for global elevation of cytoplasmic calcium. When the membrane potential is held near rest, however, the synaptic-type AChRs can promote substantial calcium influx without contributions from VDCCs. As a result, the receptors could, in principle, regulate calcium-dependent events without cell depolarization being a requirement. Lastly, calcium flux through AChRs may have the greatest impact on calcium levels in microdomains ncar the plasma membranc. In this case, the two classes of receptors could induce wholly different sets of calcium-dependent events by virtue of the receptors having different distributions in the membrane.

\section{Materials and Methods}

Cell preparations. Ciliary ganglia from 14-15-d-old chick embryos were dissected, cut into halves, incubated for $30 \mathrm{~min}$ at $37^{\circ} \mathrm{C}$ in divalent-free physiological extracellular recording solution (soln $\mathrm{H}$ without divalent cations; see below) containing $1 \mathrm{mg} / \mathrm{ml}$ collagenase, and then rinsed and triturated as previously described (Margiotta and Gurantz, 1989). The dissociated cells were plated on either glass coverslips or plastic Costar dishes coated with poly-D-lysine, and incubated in complete culture medium containing 3\% ( $\mathrm{v} / \mathrm{v})$ embryonic chick eye extract (Nishi and Berg, 1981) for $1 \mathrm{hr}$ at $37^{\circ} \mathrm{C}$ to allow attachment of cells to the substratum prior to experimental analysis.

Electrophysiology. Conventional whole-cell voltage-clamp techniques were employed as previously described (Hamill et al., 1981) to record nicotine- and voltage-induced membrane currents from cells $1-5 \mathrm{hr}$ after plating. Patch pipettes were pulled from 1.5-mm-o.d. borosilicate glass and had resistances of 1-2 M 2 when filled with any of the intracellular solutions (see below). An Axopatch $1 \mathrm{C}$ amplifier (Axon Instruments) was used to establish voltage clamp. Series resistances in the whole-cell configuration were 3-4 M $\Omega$. For reversal potential measurements, a 4\% agar bridge (in intracellular solns A or B; see below) was used between the bath solution and the bath ground electrode to minimize differences in junction potentials along the recording circuit. Voltage ramps were applied to neurons by changing the membrane voltage linearly from -90 to $+40 \mathrm{mV}$ in $200 \mathrm{msec}$. Air pressure from a small micropipette (puffer pipette; about $10 \mu \mathrm{m}$ i.d.) was used to apply $1-50$ $\mu \mathrm{M}$ nicotine or $25 \mathrm{~mm}$ potassium chloride (soln I) to individual neurons as previously described (Margiotta and Gurantz, 1989). Steady-state concentrations were achieved within $200 \mathrm{msec}$ (Zhang et al., 1994). Bath perfusion $(2 \mathrm{ml} / \mathrm{min}$ ) removed the stimulant and reduced responses to baseline in less than $30 \mathrm{sec}$. Recordings of membrane currents were stored on videotape (Neuro Corder DR-390 with Panasonic AG-1260), filtered at $0.5-1 \mathrm{kHz}$, and analyzed using AXOGRAPH software (Axon Instruments) as previously described (Zhang et al., 1994).

Relative membrane permeabilities to various cations were determined using the Goldman-Hodgkin-Katz (GHK) current equation (Lewis, 1979) where the current carried by each ion $s$ is given by

$$
i_{s}=P_{s} z_{s}^{2} \frac{E F^{2}}{R T}\left(\frac{[s]_{o}-[s]_{i} \exp \left(\frac{z_{s} F E}{R T}\right)}{1-\exp \left(\frac{z_{s} F E}{R T}\right)}\right),
$$

with $P_{s}$ being the permeability of the membrane to ion $s, z$ being the charge on $s, E$ being the membrane potential, and $F, R$, and $T$ being Faraday's constant, the gas constant, and the absolute temperature, respectively. Ion activities were calculated for each solution (Robinson and Stokes, 1959; Butler, 1968) for use in the equation.

One set of reversal potential measurements was made in solutions containing sodium and calcium as the only permeant cations (intracellular soln $A$ and extracellular solns $D-G$ ). Assuming independent flux of ions and intracellular calcium concentration is zero, the following equation can be used to represent the total nicotine-induced current:

$$
\begin{aligned}
\sum_{i}= & i_{\mathrm{Ca}}+i_{\mathrm{Na}}=4 P_{\mathrm{Ca}} \frac{E F^{2}}{R T}\left(\frac{\left[\mathrm{Ca}^{2+}\right]_{o}}{1-\exp \left(\frac{2 E F}{R T}\right)}\right) \\
& +P_{\mathrm{Na}} \frac{E F^{2}}{R T}\left(\frac{\left[\mathrm{Na}^{+}\right]_{o}-\left[\mathrm{Na}^{+}\right]_{i} \exp \left(\frac{E F}{R T}\right)}{1-\exp \left(\frac{E F}{R T}\right)}\right)
\end{aligned}
$$

At the reversal potential $\left(E_{\text {rev }}\right)$, the sum of the currents equals zero. Solving for the permeability of the receptor for calcium relative to sodium yields

$$
\left(\frac{P_{\mathrm{Ca}}}{P_{\mathrm{Na}}}\right)=\frac{\left(1+\exp \left(\frac{E_{\mathrm{rev}} F}{R T}\right)\right)\left(\left[\mathrm{Na}^{+}\right]_{i} \exp \left(\frac{E_{\mathrm{rev}} F}{R T}\right)-\left[\mathrm{Na}^{+}\right]_{o}\right)}{4\left[\mathrm{Ca}^{2+}\right]_{o}} .
$$

In a second set of experiments, $P_{\mathrm{Cs}} / P_{\mathrm{Na}}$ and $P_{\mathrm{Ca}} / P_{\mathrm{Cs}}$ were determined and then used to calculate $P_{\mathrm{Ca}} / P_{\mathrm{Na}}$. For this purpose, reversal potentials were measured first in solutions containing extracellular sodium (soln B) and intracellular cesium (soln E). Again, the total nicotine-induced current equals the sum of the currents carried by each cation present:

$$
\begin{aligned}
\sum_{i}=i_{\mathrm{Na}}+i_{\mathrm{Cs}}= & P_{\mathrm{Na}} \frac{E F^{2}}{R T}\left(\frac{\left[\mathrm{Na}^{+}\right]_{o}-\left[\mathrm{Na}^{+}\right] \exp \left(\frac{E F}{R T}\right)}{1-\exp \left(\frac{E F}{R T}\right)}\right) \\
& +P_{\mathrm{Cs}} \frac{E F^{2}}{R T}\left(\frac{\left[\mathrm{Cs}^{+}\right]_{o}-\left[\mathrm{Cs}^{+}\right]_{i} \exp \left(\frac{E F}{R T}\right)}{1-\exp \left(\frac{E F}{R T}\right)}\right)
\end{aligned}
$$

If the concentrations of sodium inside the cell and cesium outside the cell are negligible, the relative permeability of the channel to cesium and sodium at the reversal potential can be represented as

$$
\left(\frac{P_{\mathrm{Cs}}}{P_{\mathrm{Na}}}\right)=\frac{\left[\mathrm{Na}^{+}\right]_{o}}{\left[\mathrm{Cs}^{+}\right]_{i} \exp \left(\frac{E_{\mathrm{rcv}} F}{R T}\right)} .
$$

When the only permeant cations were calcium outside (soln B) and cesium inside (soln D), the new measured reversal potential and the value determined for $P_{\mathrm{CS}} / P_{\mathrm{Na}}$ were used to solve for $P_{\mathrm{Ca}} / P_{\mathrm{Na}}$ according . to the equation

$$
\left(\frac{P_{\mathrm{Ca}}}{P_{\mathrm{Na}}}\right)=\frac{\left(\frac{P_{\mathrm{Cs}_{5}}}{P_{\mathrm{Na}}}\right)\left\{\left[\mathrm{Cs}^{+}\right]_{i} \exp \left(\frac{E_{\mathrm{rev}} F}{R t}\right)\left(1+\exp \left(\frac{E_{\mathrm{rev}} F}{R T}\right)\right)\right\}}{4\left[\mathrm{Ca}^{2+}\right]_{o}} .
$$

Cadmium was included as a minor constituent in some solutions as indicated in the text. To simplify calculations, the permeability of AChRs to cadmium was assumed to be negligible. For muscle AChRs, cadmium was found to be the least permeant of all divalent cations examined, a feature attributed to the formation of cadmium-chloride complexes (Adams et al., 1980).

Fluorescence measurements. Fluorescence measurements were made on cells loaded with the calcium-sensitive fluorescent dye fluo-3 and monitored with a photomultiplier in real time. The cells were attached to glass coverslips. For measurements in the absence of voltage clamp, cells were loaded by incubation for 30-45 $\mathrm{min}$ with the membranepermeant derivative fluo-3 AM at $2 \mu \mathrm{M}$ in MEM. $\alpha$ Bgt $(50 \mathrm{nM})$ was included to block $\alpha$ Bgt-AChRs. After rinsing with extracellular solution, the cells were perfused at $2 \mathrm{ml} / \mathrm{min}$ with the same solution containing $20 \mathrm{nM} \alpha \mathrm{Bgt}$ and $1 \mu \mathrm{M}$ tetrodotoxin (TTX), and stimulants were applied from a nearby micropipette as described above. In experiments where activation of both $\alpha \mathrm{Bgt}-\mathrm{AChRs}$ and mAb 35-AChRs was desired, $\alpha \mathrm{Bgt}$ was omitted, and control and drug-containing solutions were applied via a linear array of glass tubes $(250 \mu \mathrm{m}$ i.d., $350 \mu \mathrm{m}$ o.d.; Polymicro Technologies) to assure rapid delivery and improved activation of the $\alpha$ Bgt-AChR (Zhang et al., 1994). 
Epifluorescence was generated with a $100 \mathrm{~W}$ mercury light fitted with an FITC filter set (KP490/TK510/K515, Leitz) and neutral density filters $(0.5-1.0)$ to reduce photobleaching. Neurons were visualized with a $40 \times$ fluorescence oil-immersion Leitz objective. Emission fluorescence was recorded using a Nikon photometry system (P 100s) with a photomultiplier operated by a photometry controller. Analog signals were digitized and collected on an IBM-compatible computer with 486 microprocessor running pCLAMP software (Axon Instruments). Fluorescence was measured as the increase in fluorescence at peak response divided by the basal fluorescence. In some cases, responses to nicotine were normalized to responses elicited by $25 \mathrm{~mm}$ potassium solution (soln I).

When fluorescence measurements were made on voltage-clamped cells, the cells were first loaded with dye via the recording electrode which contained $50 \mu \mathrm{M}$ fluo-3 pentapotassium (soln C). Neurons were voltage clamped at $-70 \mathrm{mV}$ and stimulated either by stepping the membrane potential to $0 \mathrm{mV}$ to activate VDCCs or by applying $50 \mu \mathrm{M}$ nicotine from a micropipette to activate AChRs. Background fluorescence contributed by autofluorescence of the neuron prior to dye loading and by fluorescence from the recording pipette was negligible, constituting less than $10 \%$ of the basal fluorescence of the neuron after loading.

Fluorescence measurements of cadmium interactions with fluo- 3 were made with a Perkin-Elmer MPF4 fluorimeter. Titrations of $15 \mu \mathrm{M}$ fluo-3 pentapotassium with either calcium or cadmium werc carricd out in cuvettes as previously described (Minta et al., 1989), in both the presence and absence of EGTA. Fluorescence was measured as emission at 530 $\mathrm{nm}$ following excitation at $490 \mathrm{~nm}$.

Solutions. Solutions of the following compositions (mM) are referred to in the text by letter. Intracellular solution $A, \mathrm{NaCl}(105), \operatorname{HEPES}(10)$, EGTA (10), EDTA (10), $\mathrm{NaOH}(25) ; B, \mathrm{CsCl}(105)$, HEPES (10), EGTA (10), EDTA (10), CsOH (25); $C, \mathrm{CsCl}$ (130), HEPES (10), EGTA (2.4), fluo-3 pentapotassium (0.5), $\mathrm{CsOH}$ to $\mathrm{pH}$ 7.3. Extracellular solution $D$, $\mathrm{CaCl}_{2}(70)$, HEPES (10); $E, \mathrm{NaCl}(130$ or 140), HEPES (10); $F, \mathrm{NaCl}$ (100), $\mathrm{CaCl}_{2}(20)$, HEPES (10); $G, \mathrm{NaCl}(127), \mathrm{CaCl}_{2}(2)$, HEPES (10); $H, \cdot \mathrm{KCl}(5.4), \mathrm{NaCl}(116.4), \mathrm{MgSO}_{4}(0.8)$, glucose (5.6), sodium succinate (0.4), succinic acid (0.6), HEPES (10), $\mathrm{CaCl}_{2}$ (2 or 10); $I, \mathrm{KCl}(25), \mathrm{NaCl}$ (96), $\mathrm{MgSO}_{4}(0.8)$, glucose (5.6), sodium succinate (0.4), succinic acid (0.6), HEPES (10), $\mathrm{CaCl}_{2}$ (2 or 10). For all extracellular solutions, $\mathrm{pH}$ was adjusted to 7.3 with the hydroxide of the major cation. For all intracellular solutions the indicated concentration of hydroxide was required to adjust the $\mathrm{pH}$ to 7.3 in the presence of the divalent cation chelators.

Materials. White Leghorn chick embryos were obtained locally and maintained at $37^{\circ} \mathrm{C}$ in a humidified incubator. $\alpha \mathrm{Bgt}$ and neuronal bungarotoxin (nBgt) were purified from Bungarus multicinctus venom (Ravdin et al., 1981). Fluo-3 AM and fluo-3 pentapotassium were purchased from Molecular Probes. $\omega$-Conotoxin was purchased from RBI. All other compounds were purchased from Sigma unless otherwise indicated.

\section{Results}

\section{Calcium currents through mAb 35-AChRs}

To determine whether mAb 35-AChRs are capable of conducting calcium currents, the receptors were stimulated under voltage-clamp conditions with calcium being the only extracellular cation present. This was achieved by substituting $70 \mathrm{~mm}$ calcium for all cations normally present and balancing the osmolarity with sucrose. Currents through $\alpha \mathrm{Bgt}-\mathrm{AChRs}$ were blocked by preincubating the cells with $50 \mathrm{~nm} \alpha \mathrm{Bgt}$ (Zhang et al., 1994). The toxin concentration was chosen to exceed the $K_{D}$ for binding by more than 50-fold (Vijayaraghavan et al., 1992), saturating the sites and completely inhibiting responses from the receptors. Applying $10 \mu \mathrm{M}$ nicotine from a puffer pipette to the cells voltage clamped at $-70 \mathrm{mV}$ elicited an inward current from $\mathrm{mAb} 35-\mathrm{AChRs}$ equivalent in size to that observed when sodium was the only extracellular cation available (Fig. 1). Averaging the responses from a number of neurons yielded values of $668 \pm 94 \mathrm{pA}$ (mean $\pm \mathrm{SEM}, n=10$ cells) in $70 \mathrm{~mm}$ calcium, and $474 \pm 44 \mathrm{pA}(n=14)$ in $140 \mathrm{~mm}$ sodium. The values are not significantly different.

\section{A $\quad 70 \mathrm{mM}$ calcium}

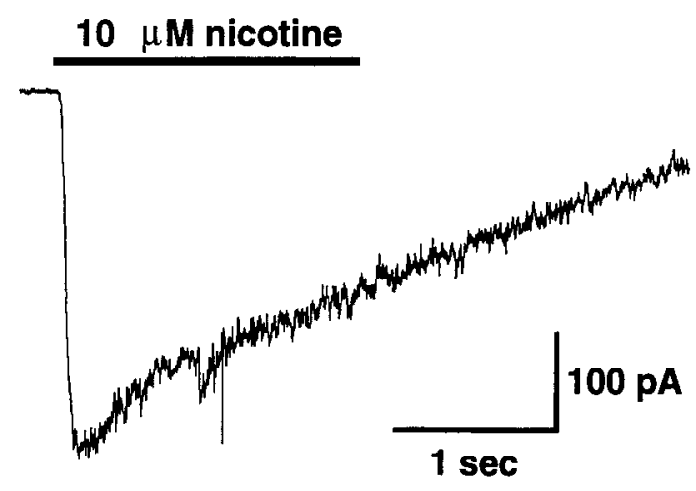

B

\section{$140 \mathrm{mM}$ sodium}

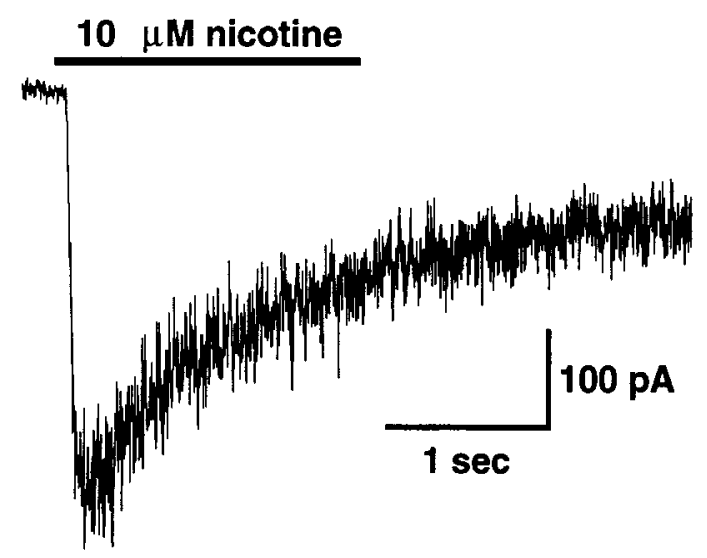

Figure 1. Comparison of calcium and sodium currents through voltage-clamped mAb 35-AChRs. Neurons were incubated with $50 \mathrm{nM} \alpha \mathrm{Bgt}$ to block $\alpha$ Bgt-AChRs. Application of $10 \mu \mathrm{M}$ nicotine for $2 \mathrm{sec}$ (horizontal bars) induced currents $(A)$ in a neuron bathed in $70 \mathrm{~mm}$ calcium (soln $D$ ) and $(B)$ in a neuron bathed in $140 \mathrm{~mm}$ sodium (soln E) as the only extracellular cation. In both cases the neurons were voltage clamped at $-70 \mathrm{mV}$, and cesium (soln B) represented the only supplied intracellular cation. The currents were selected for being representative in amplitude and time course; they were similar to each other in peak amplitude but different in nicotine-induced noise.

Nicotine-induced currents mediated by calcium differed from those mediated by sodium with respect to noise. Smaller agonist-induced current fluctuations were observed in $70 \mathrm{~mm}$ calcium than in 140 mm sodium. A similar phenomenon has been reported for other AChRs and was attributed to a decrease in single-channel conductance with increasing concentrations of extracellular calcium (Lewis, 1979; Dani and Eisenman, 1987; Decker and Dani, 1990; Zhang and Feltz, 1990; Vernino et al., 1992). If single-channel currents are indecd smaller in the presence of $70 \mathrm{~mm}$ calcium, a greater probability of channel opening or a larger open time must account for the whole-cell currents being equivalent in amplitude. The responses in the two ionic conditions also appeared to differ in time course with nicotineinduced calcium currents decaying more slowly than those ob- 
A
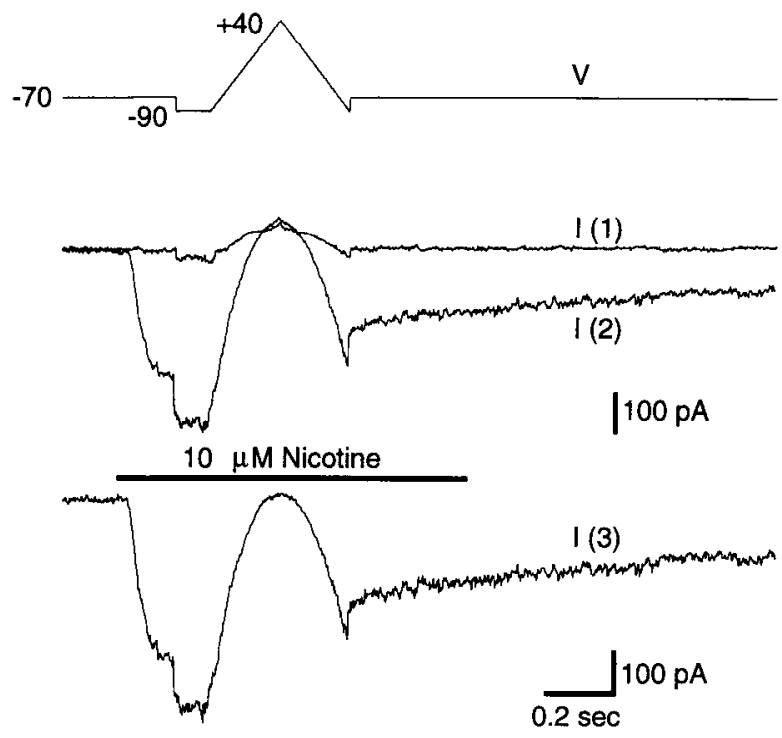

B

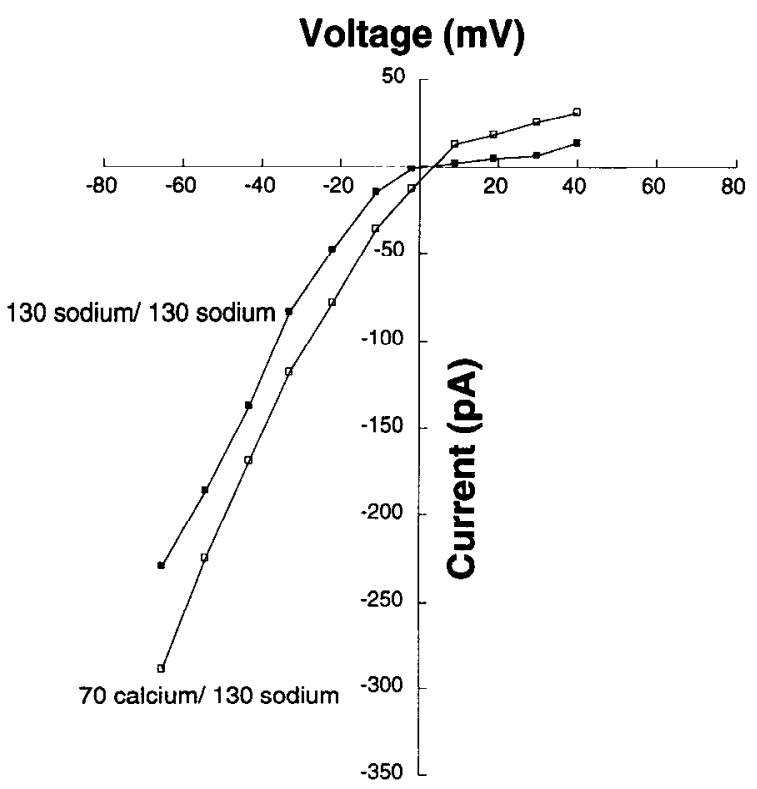

Figure 2. Current-voltage relationship for voltage-clamped $\mathrm{mAb} 35$ AChR currents in extracellular solutions of two ionic compositions. $A$, A voltage ramp (top trace, $V$ ) was applied via the recording electrode (soln B) to a neuron bathed in $70 \mathrm{~mm}$ calcium (soln D) before [middle trace, $I(1)$ ] and during [middle trace, $I(2)$ ] application of $10 \mu \mathrm{M}$ nicotine (horizontal bar). The net nicotine-induced current [bottom trace, I(3)] was calculated as the difference between the middle two traces. $B$, Results from a neuron bathed in $130 \mathrm{~mm}$ sodium ( 1 ; soln E) and from a neuron bathed in $70 \mathrm{~mm}$ calcium ( $\square$; soln $D)$ plus $0.2 \mathrm{~mm}$ cadmium while dialyzing the interior in both cases with $130 \mathrm{~mm}$ sodium (soln A). TTX $(1 \mu \mathrm{M})$ was present in both cases. Responses induced by $50 \mu \mathrm{M}$ nicotine reversed around $0 \mathrm{mV}$ in the first case (as expected for internal and external solutions of equivalent composition) and around $5 \mathrm{mV}$ in the second. Equation 1 yielded a value of about $1: 1$ for the relative permeabilities of calcium and sodium calculated from a number of such trials (see Table 1).

served in sodium. No significant difference, however, emerged when the time course of decay was fit with an exponential in each case and time constants were calculated. Values of $6.1+$ 0.9 (mean \pm SEM, $n=14)$ and $4.8 \pm 0.3(n=19)$ sec were obtained for the time constants describing decay of the responses in calcium and sodium, respectively. A single exponential was adequate to describe the decay in both salt solutions.

\section{Relative permeabilities of $\mathrm{mAb} 35-A C h R$ s to calcium and sodium}

The relative permeabilities of $\mathrm{mAb} 35-\mathrm{AChRs}$ to sodium and calcium were calculated directly from the GHK Equation 1 using measured values of the nicotinic reversal potential obtained in solutions of different ionic composition. Measurements of the reversal potential were carried out using voltage-clamp techniques to apply a ramp of membrane voltage, changing the holding potential linearly from -90 to $+40 \mathrm{mV}$ during a 200 msec time window within a $2 \mathrm{sec}$ period of agonist application. The ramp was initiated $350 \mathrm{msec}$ after the application of agonist had begun, thereby avoiding the steepest portion of the decay profile resulting from desensitization. Evidence that desensitization did not influence the results was provided by the observation that the measured value of the reversal potential was not changed by reversing the directionality of the ramp, that is, going from +40 to $-90 \mathrm{mV}$. TTX at $1 \mu \mathrm{M}$ was included in the extracellular solution to block voltage-gated sodium currents; cadmium at $0.2 \mu \mathrm{M}$ was included to block voltage-gated calcium currents. In some cases cesium was used as the principal intracellular cation to block voltage-gated potassium currents. Residual unblocked voltage-gated currents and leak currents induced by the ramp were measured in the absence of agonist and then digitally subtracted from the total current in the presence of agonist to isolate the nicotine-induced current. Nicotine at $10 \mu \mathrm{M}$ was used as the agonist, and in most experiments $\alpha \mathrm{Bgt}$ was omitted. No contribution from $\alpha$ Bgt-AChRs was expected because of the relatively slow method of agonist application, which previous experiments have shown fails to elicit a detectable $\alpha$ Bgt-AChR current response (Vijayaraghavan et al., 1992; Zhang et al., 1993). In addition, the voltage ramp was applied at a time when current responses from $\alpha$ Bgt-AChRs would have largely decayed, had they existed. The large and small components of the $\alpha \mathrm{Bgt}-\mathrm{AChR}$ response (elicited by rapid application of agonist) have decay constants of about 13 and $200 \mathrm{msec}$, respectively (Zhang et al., 1994). In experiments done in the presence of $\alpha$ Bgt, no significant difference was noted in the reversal potentials of the current.

As a test of the technique, reversal potentials were determined in solutions with equimolar concentrations of sodium (130 mM) being the sole source of cations both in the internal and external solutions. As predicted, the response reversed at $0 \mathrm{mV}$ (Fig. 2, Table 1). When $70 \mathrm{~mm}$ calcium was the sole source of cations in the external solution and $130 \mathrm{~mm}$ sodium the sole source in the internal solution, a reversal potential of about $+4 \mathrm{mV}$ was obtained (Fig. 2, Table 1). In both conditions the $I-V$ relationship was approximately linear at negative voltages and showed strong rectification at positive voltages (though in $70 \mathrm{~mm}$ calcium the rectification appeared slightly reduced). Similar $I-V$ relationships were obtained for these receptors in neurons bathed in solutions having a mixture of sodium and calcium ions. Inward rectification has previously been reported for several classes of neuronal AChRs and has been attributed in part to a decreased probability of channel opening at more positive potentials and a partial magnesium ion block (Yawo, 1989; Bertrand et al., 1990; Couturier et al., 1990a,b; Ifune and Steinbach, 1990, 1992; Mathie et al., 1990; Zhang and Feltz, 1990; Sands and Barrish, 1991, 1992). 
Table 1. Relative ion permeabilities of mAb 35-AChRs

\begin{tabular}{llllr}
{$[$ Ion] } & Rel permeability & $n$ \\
\hline $130 \mathrm{Na}(\mathrm{E})$ & [Ion] $]_{i}$ & $E_{\mathrm{rev}}$ & \multicolumn{1}{c}{$n$} \\
$127 \mathrm{Na}, 2 \mathrm{Ca}, 0.2 \mathrm{Cd}(\mathrm{G})$ & $130 \mathrm{Na}(\mathrm{A})$ & $+0.5 \pm 1.6$ & $P_{\mathrm{Na}} / P_{\mathrm{Na}} 1.0 \pm 0.1$ & 18 \\
$127 \mathrm{Na}, 2 \mathrm{Ca}, 1 \mathrm{Cd}(\mathrm{G})$ & $134 \mathrm{Na}\left(\mathrm{A}^{*}\right)$ & $+1.5 \pm 1.0$ & $P_{\mathrm{Ca}} / P_{\mathrm{Na}} 5.1 \pm 2.2$ & 11 \\
$100 \mathrm{Na}, 20 \mathrm{Ca}, 0.2 \mathrm{Cd}(\mathrm{F})$ & $134 \mathrm{Na}\left(\mathrm{A}^{*}\right)$ & $+0.0 \pm 1.1$ & $P_{\mathrm{Ca}} / P_{\mathrm{Na}} 2.1 \pm 2.1$ & 4 \\
$100 \mathrm{Na}, 20 \mathrm{Ca}, 1 \mathrm{Cd}(\mathrm{F})$ & $134 \mathrm{Na}\left(\mathrm{A}^{*}\right)$ & $-2.4 \pm 1.3$ & $P_{\mathrm{Ca}} / P_{\mathrm{Na}} 0.7 \pm 0.2$ & 16 \\
$70 \mathrm{Ca}, 0.2 \mathrm{Cd}(\mathrm{D})$ & $134 \mathrm{Na}\left(\mathrm{A}^{*}\right)$ & $-1.0 \pm 0.1$ & $P_{\mathrm{Ca}} / P_{\mathrm{Na}} 0.9 \pm 0.2$ & 6 \\
$70 \mathrm{Ca}, 1 \mathrm{Cd}(\mathrm{D})$ & $130 \mathrm{Na}(\mathrm{A})$ & $+4.0 \pm 1.8$ & $P_{\mathrm{Ca}} / P_{\mathrm{Na}} 1.7 \pm 0.2$ & 9 \\
$70 \mathrm{Ca}(\mathrm{D})$ & $130 \mathrm{Na}(\mathrm{A})$ & $+7.8 \pm 0.5$ & $P_{\mathrm{Ca}} / P_{\mathrm{Na}} 2.1 \pm 0.1$ & 12 \\
$130 \mathrm{Na}(\mathrm{E})$ & $130 \mathrm{Na}(\mathrm{A})$ & $+2.0 \pm 0.5$ & $P_{\mathrm{Ca}} / P_{\mathrm{Na}} 1.5 \pm 0.1$ & 5 \\
$130 \mathrm{Na}, 1 \mathrm{Cd}(\mathrm{E})$ & $130 \mathrm{Cs}(\mathrm{B})$ & $-0.2 \pm 2.4$ & $P_{\mathrm{Na}} / P_{\mathrm{Ca}} 1.0 \pm 0.1$ & 11 \\
$70 \mathrm{Ca}, 1 \mathrm{Cd}(\mathrm{D})$ & $130 \mathrm{Cs}(\mathrm{B})$ & $+1.9 \pm 2.2$ & $P_{\mathrm{Na}} / P_{\mathrm{Cs}} 1.0 \pm 0.1$ & 8 \\
Calculated from permeabilities relative to Cs: & & $P_{\mathrm{Ca}} / P_{\mathrm{Cs}} 1.2 \pm 0.1$ & 12 \\
\end{tabular}

Relative permeabilities of $\mathrm{mAb} 35-\mathrm{AChRs}$ were determined for calcium and sodium by measuring the reversal potential of the nicotinic currents in the presence of the indicated cations. The solutions are indicated in parentheses $\left(A^{*}=A+\right.$ $4 \mathrm{~mm} \mathrm{NaCl}$ ). In all cases, $1 \mu \mathrm{M}$ TTX was present to block sodium channel activation. In some cases $\alpha$ Bgt was included to insure blockade of $\alpha \mathrm{Bgt}-\mathrm{AChRs}$, even though the method of agonist application would not have activated $\alpha \mathrm{Bgt}-$ AChRs. In $70 \mathrm{~mm}$ calcium without cadmium, $2 \mu \mathrm{M}$ w-conotoxin was added to block voltage-gated calcium channels. [Ion], cation composition of the extracellular solution; [Ion], cation composition of the solution in the recording pipette; $E_{\text {rev }}$, reversal potential in $\mathrm{mV}$ determined by constructing an $I-V$ plot of the data as done in Figure 2 ; Rel permeability, relative permeabilities of the receptors calculated using the mean value of the reversal potential and Equations $1-3 ; n$, number of neurons. For reversal potentials, the values represent the mean $\pm \mathrm{SEM}$ for the indicated $n$; for relative permeabilities the values represent the mean \pm the average spread resulting from calculating extreme values using the mean reversal potential \pm the SEM. In all cases the relative calcium-to-sodium permeabilities were in the $1-2$ range except in $2 \mathrm{~mm}$ calcium, where small errors in the reversal potential introduce large errors in the permeability calculation. [Cadmium had little effect: mean reversal potentials in $0.2 \mathrm{vs} 1 \mathrm{~mm}$ cadmium were not significantly different for any test condition except $70 \mathrm{~mm}$ calcium, where they were marginally different $(0.05>p>0.02$, two-tailed $t$ test $) ; 1 \mathrm{~mm}$ cadmium did not affect the measured $P_{\mathrm{Na}} / P_{\mathrm{Cs}}$.]

Using the measured values of the reversal potential in the GHK Equation 1 indicated that $\mathrm{mAb} 35-\mathrm{AChRs}$ are at least as permeable to calcium as to sodium (Table 1). This was true whether calcium and sodium permeabilities were compared directly or whether each was compared first to cesium and the ratios then used to calculate the relative calcium and sodium permeabilities (Eqs. 2, 3). At physiological concentrations of calcium (about $2 \mathrm{~mm}$ ), the measured ratio of permeabilities to calcium versus sodium appeared somewhat higher than those determined in other concentrations of calcium and was significantly greater than $1: 1$. This was true whether or not the 0.2 and $1 \mathrm{~mm}$ cadmium data were combined. The reasons for the high value are not clear but it should be noted that in contrast to measurements in 20 and $70 \mathrm{~mm}$ calcium, a small systematic error in determining the reversal potential in $2 \mathrm{~mm}$ calcium would produce a large error in the calculated permeability ratio.

The cadmium used to block voltage-gated calcium currents did not interfere with the determination of calcium permeabilities for $\mathrm{mAb} 35$-AChRs and did not appear to be very permeant itself. Raising the cadmium concentration from 0.2 to $1 \mathrm{~mm}$ did not significantly alter the values determined for the reversal potcntial in any case cxccpt that of $70 \mathrm{~mm}$ calcium, where the difference was marginally significant $(0.05>p>0.02$; Table 1). (The difference might have resulted from inadequacies in the subtraction method for eliminating voltage-gated currents, which would be most apparent in high calcium.) Substituting $\omega$-conotoxin, a specific blocker of $\mathrm{N}$-type voltage-gated calcium channels, for the cadmium yielded a similar value for $P_{\mathrm{Ca}} / P_{\mathrm{Na}}$, supporting the contention that cadmium did not contribute significantly to the determination. Evidence that the receptors may have a low permeability for cadmium also comes from the sodium and cesium results, where $1 \mathrm{~mm}$ cadmium had no effect on the value of $P_{\mathrm{Na}} / P_{\mathrm{Cs}}$ obtained (Table 1). Taken together, the data indicate that $\mathrm{mAb} 35-\mathrm{AChRs}$ are quite permeable to calcium as previously reported for other neuronal AChRs (Fieber and Adams, 1991; Sands and Barish, 1991; Mulle et al., 1992; Vernino et al., 1992).

\section{mAb 35-AChR effects on intracellular calcium}

Although measuring relative permeabilities provides a means of assessing the ion selectivity of channels, the measurements do not necessarily indicate whether the receptors can significantly elevate intracellular calcium levels. Usually calcium permeability measurements are made in the presence of high concentrations of calcium, which may cause surface screening effects. As recently pointed out (Schneggenburger et al., 1993), this could introduce a voltage dependence to the determination that could limit its applicability to membrane potentials near the reversal potential. Measurements in low calcium concentrations would be less subject to the effects of surface screening, but greater uncertainty is associated with the calculation of relative calcium permeability in this case, as noted above. The GHK equation also requires certain assumptions concerning a continuous voltagc change across the membrane and the absence of interactions among permeant ions that may not hold in all conditions. Accordingly, it was important to determine directly whether $\mathrm{mAb}$ 35-AChRs elevate intracellular calcium levels in neurons bathed in physiological concentrations of calcium when the membrane potential is allowed to fluctuate.

To do this, neurons were loaded with the calcium-sensitive dye fluo-3 AM and preincubated with $50 \mathrm{nM} \alpha \mathrm{Bgt}$ to block responses from $\alpha$ Bgt-AChRs. Application of $50 \mu \mathrm{M}$ nicotine from a puffer pipette to individual neurons elicited a sizable fluorescence response (Fig. $3 \mathrm{~A}$ ). Depolarizing the cells with 25 


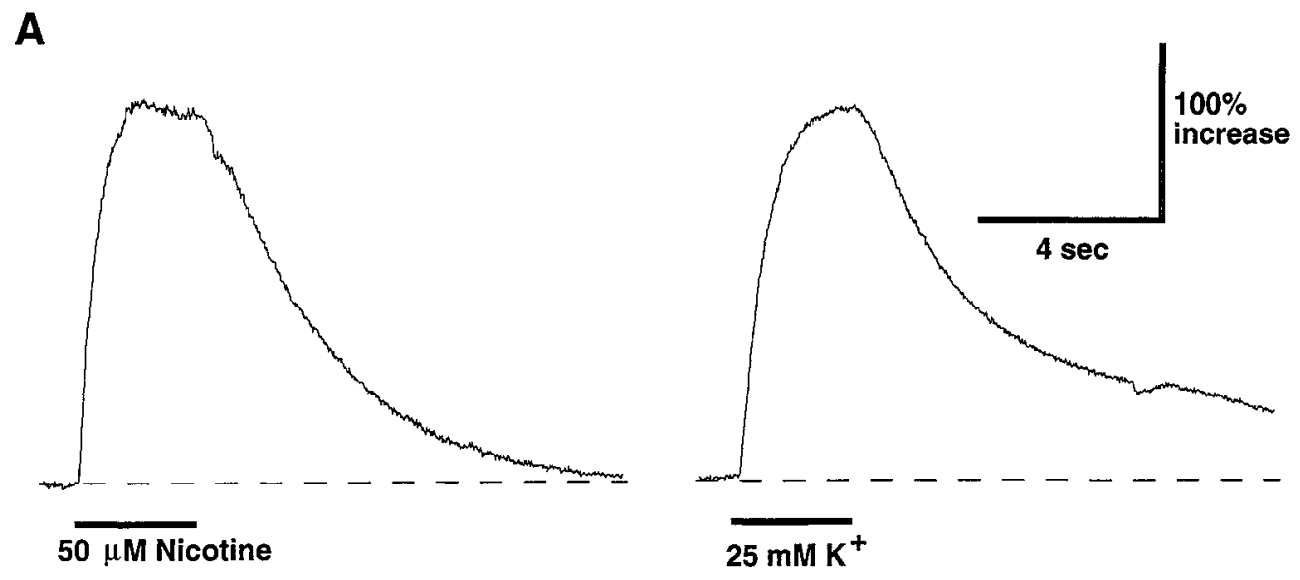

Figure 3. Elevation of intracellular calcium levels by $\mathrm{mAb} 35-\mathrm{AChRs}$ in neurons without voltage clamp. $A$, Fluorescence responses. Neurons were loaded with fluo-3 AM in the presence of $50 \mathrm{nM} \alpha \mathrm{Bgt}$ and stimulated individually with $50 \mu \mathrm{M}$ nicotine (left) or 25 mM potassium (right) for the indicated times (horizontal bars). Fluorescence responses from individual neurons in 2 mM calcium (soln $\mathrm{H}$ ) were quantified with a photomultiplier tube in real time, and the net responses are displayed as a percentage of the basal fluorescence. $B$, Pharmacology of the fluorescence response. Neurons were tested as in $A$ after incubation in the absence of antagonists (control) or in $100 \mu \mathrm{M}$ $d$-tubocurarine $(d T C), 100$ nм neuronal bungarotoxin $(n B g t)$, or $1 \mathrm{~mm}$ EGTA substituted for the calcium normally present $(E G T A)$. Data compiled from the number of neurons indicated in $p a$ rentheses represent the mean \pm SEM and are expressed as a fraction of the response obtained from control cells in the same experiment in each case.

\section{B}

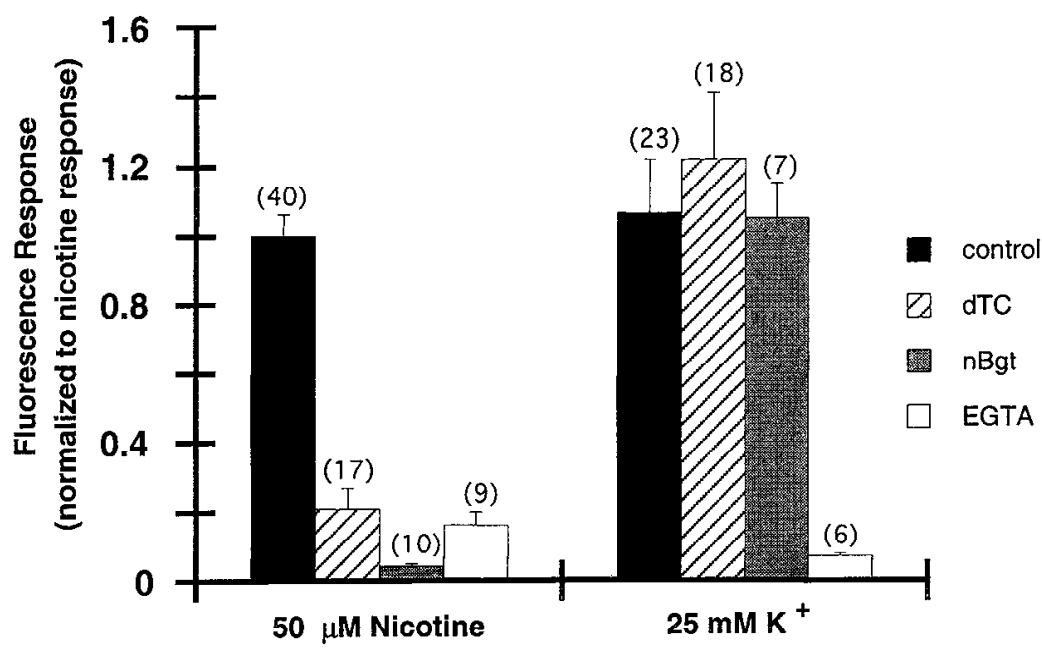

mM potassium to activate voltage-dependent calcium channels (VDCCs) induced a mean response that was only slightly larger. The nicotinic response was blocked by $100 \mu \mathrm{M} d$-tubocurarine (d-TC), as expected for nicotinic receptors. $\mathrm{nBgt}$, which at 100 nM blocks the current associated with activation of $\mathrm{mAb} 35-$ AChRs (Ravdin and Berg, 1979; Halverson and Berg, 1987), blocked the nicotine-induced fluorescence as well (Fig. $3 B$ ). Neither of these nicotinic antagonists had any effect on the $25 \mathrm{~mm}$ potassium response. Substituting $1 \mathrm{~mm}$ EGTA for calcium in the perfusion and in the puffer pipette abolished both the nicotine- and the potassium-induced responses, confirming that the intracellular increases were dependent on extracellular calcium (Fig. 3B).

The concentration dependence of the nicotine-induced fluorescence response was examined over a 50 -fold range of agonist by varying the nicotine concentration in the puffer pipette. Again, $50 \mathrm{nM} \alpha$ Bgt was used to block $\alpha$ Bgt-AChRs. At $1 \mu \mathrm{M}$, nicotine elicited a response that was barely detectable over background, while $10 \mu \mathrm{M}$ elicited a near-maximal response. The same range of nicotine concentrations elicited a large fraction of the current possible from $\mathrm{mAb} 35-\mathrm{AChRs}$ (Fig. 4). Taken together, the blockade by $\mathrm{nBgt}$ and $\mathrm{d}-\mathrm{TC}$, the resistance to $\alpha \mathrm{Bgt}$, and the nicotine concentration dependence indicated that the fluorescence response arises from activation of $\mathrm{mAb} 35-\mathrm{AChRs}$ on the neurons.
Role of VDCCs in calcium increases initiated by activation of neuronal $A C h R s$

Previous use of a fluorescence assay showed that activation of $\alpha \mathrm{Bgt}-\mathrm{AChRs}$ on the neurons also increases intracellular calcium levels. Though $\alpha$ Bgt-AChRs are likely to have a substantial calcium permeability by virtue of their constituent $\alpha 7$ subunits (Galzi et al., 1992; Seguela et al., 1993; Vernallis et al., 1993), much of the calcium increase resulting from receptor activation appeared to depend on VDCCs. This was inferred from the finding that cadmium blocks most of the fluorescence response (Vijayaraghavan et al., 1992) without blocking the nicotineinduced current attributed to $\alpha$ Bgt-AChRs (Zhang et al., 1994). Similarly, VDCC blockers prevent calcium-dependent neurite retraction that otherwise results from activation of $\alpha \mathrm{Bgt}-\mathrm{AChRs}$ on neurons in cell culture (Pugh and Berg, 1994). This precedent made it important to evaluate the contribution of VDCCs to calcium increases caused by activation of mAb 35-AChRs. In addition, experiments were carried out to compare $\alpha \mathrm{Bgt}-\mathrm{AChRs}$ and $\mathrm{mAb} 35-\mathrm{AChRs}$ with respect to their abilities to elevate intracellular calcium levels in the neurons. Previous fluorescence experiments on $\alpha$ Bgt-AChRs had not used the rapid method of agonist application that is required to elicit large currents through the receptors.

Cadmium, which prevents voltage-activated calcium currents 


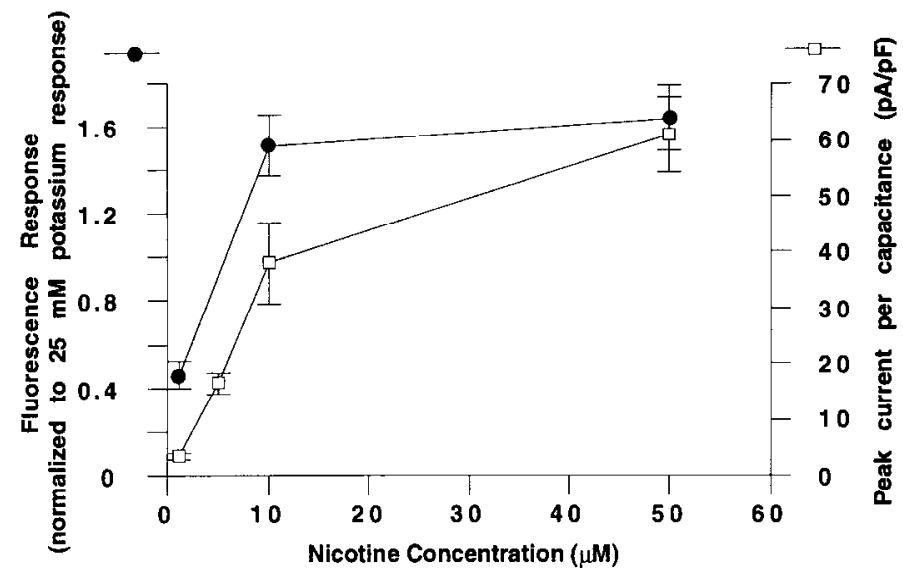

Figure 4. Dose-response curves for the nicotine-induced fluorescence and current responses of $\mathrm{mAb} 35$-AChRs. Fluorescence responses (๑) were obtained from neurons loaded with fluo-3 AM and were normalized to those obtained with $25 \mathrm{~mm}$ potassium from the same cells. Nicotine-induced currents $(\square)$ wcre mcasurcd in ncurons voltagc clamped at $-70 \mathrm{mV}$ and were normalized for cell capacitance. $\alpha \mathrm{Bgt}(50 \mathrm{nM})$ was present to block $\alpha \mathrm{Bgt}$-AChRs. The indicated concentrations of nicotine were applied individually to cells from a puffer pipette. The cells were bathed in $2 \mathrm{mM}$ calcium (soln $H$ ). Data represent the mean \pm SEM of 15 cells each.

in chick ciliary ganglion neurons (Yawo and Momiyama, 1993), was used as a selective blocker of VDCCs. Neurons were incubated in $0.2 \mathrm{~mm}$ cadmium with $\alpha$ Bgt present to block the $\alpha$ Bgt-AChRs. In neurons voltage clamped at $-70 \mathrm{mV}, 50 \mu \mathrm{M}$ nicotine induced peak whole-cell currents of $85.2 \pm 10.6$ (mean $\pm \mathrm{SEM}, n=9$ cells) and $70.8 \pm 8.7 \mathrm{pA} / \mathrm{pF}(n=7)$ in the presence and absence of $0.2 \mathrm{~mm}$ cadmium, respectively. The inability of cadmium to inhibit the $\mathrm{mAb} 35$-AChR current made it a good agent for dissecting the fluorescence response below into components derived from activation of VDCCs versus AChRs.

Cells were loaded with fluo-3 AM and challenged with nicotine from a large-bore pipette. The large bore achieved more rapid application of agonist than the puffer pipette and, as a result, induced activation of $\alpha$ Bgt-AChRs (Zhang et al., 1994), permitting a comparison with mAb 35-AChRs. Agonist concentration (1-50 $\mu \mathrm{M}$ nicotine) and the presence or absence of $\alpha \operatorname{Bgt}(50 \mathrm{~nm})$ were used to separate the responses initiated by each AChR subtype. At the lowest nicotine concentration (1 $\mu \mathrm{M}), \alpha \mathrm{Bgt}-\mathrm{AChRs}$ dominated the response as indicated by the ability of $\alpha$ Bgt to block the nicotine-induced fluorescence (Fig. $5 A$ ). Cadmium was also effective at blocking the $1 \mu \mathrm{M}$ nicotine response, indicating that $\alpha \mathrm{Bgt}-\mathrm{AChRs}$ induce the increase in intracellular calcium by activating VDCCs. At $10 \mu \mathrm{M}$ nicotine the fluorescence response was triggered by $\mathrm{mAb} 35-\mathrm{AChRs}$ since $\alpha$ Bgt had no effect. In this case, cadmium again achieved extensive blockade as it did in the case of fluorescence induced by $\alpha$ Bgt-AChRs. At the highest concentration tested, $50 \mu \mathrm{M}$, most of both classes of AChRs should have been activated, but the cadmium blockade demonstrated that VDCCs still accounted for most, if not all, of the fluorescence response. The residual fluorescence signal was too small to quantify reliably. Control experiments showed that cadmium blocked the fluorescence response induced by $25 \mathrm{~mm}$ potassium, and blocked most of the fluorescence signal resulting from activation of VDCCs in neurons by stepping the voltage from -70 to $0 \mathrm{mV}$ (Fig. $5 B$ ).
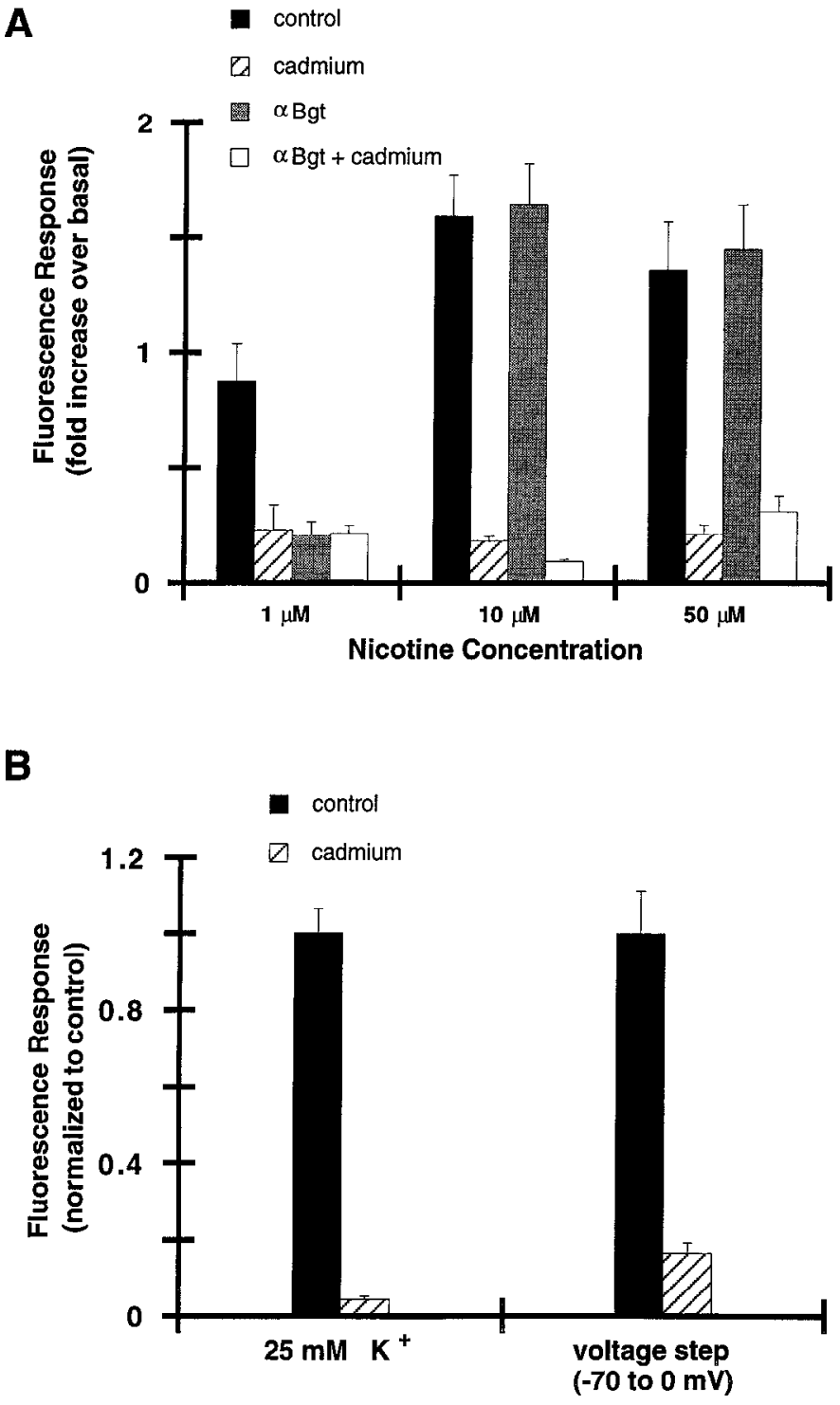

Figure 5. Cadmium blockade of fluorescence responses induced by $\mathrm{mAb} 35-\mathrm{AChRs}$ and by $\alpha \mathrm{Bgt}-\mathrm{AChRs}$. $A$, Neurons were loaded with fluo-3 AM and challenged with the indicated concentration of nicotine from a large-bore pipette to achieve rapid application of agonist. Peak fluorescence responses were quantified and expressed as $n$-fold increase over basal fluorescence. Conditions represent control cells (solid bars) or cells incubated with $0.2 \mathrm{~mm}$ cadmium (hatched bars), $50 \mathrm{nM} \alpha \mathrm{Bgt}$ (stippled bars), or $50 \mathrm{~nm} \alpha \mathrm{Bgt}$ plus $0.2 \mathrm{~mm}$ cadmium (open bars). $B$, Neurons either were loaded with fluo-3 AM and challenged with $25 \mathrm{mM}$ potassium from a puffer pipette (soln I) in the presence (hatched bars) or absence (solid bars) of $0.2 \mathrm{~mm}$ cadmium (left), or were voltage clamped, loaded with fluo-3 pentapotassium from the recording electrode (soln C), and voltage stepped from -70 to $0 \mathrm{mV}$ to activate VDCCs in the presence (hatched bars) or absence (solid bars) of $0.2 \mathrm{~mm}$ cadmium (right). The extracellular solution in all cases contained $2 \mathrm{~mm}$ calcium (soln $\mathrm{H}$ ). At low nicotine concentrations $\alpha \mathrm{Bgt}-\mathrm{AChRs}$ dominate the nicotinic response, while at high nicotine concentrations $\mathrm{mAb} 35-\mathrm{AChRs}$ do so. Cadmium blocks nearly as much nicotine-induced fluorescence at all agonist concentrations as it does the potassium- and voltage stepinduced fluorescence, indicating that VDCCs contribute a large portion of the increase in intracellular calcium resulting from activation of both classes of AChRs. 
A
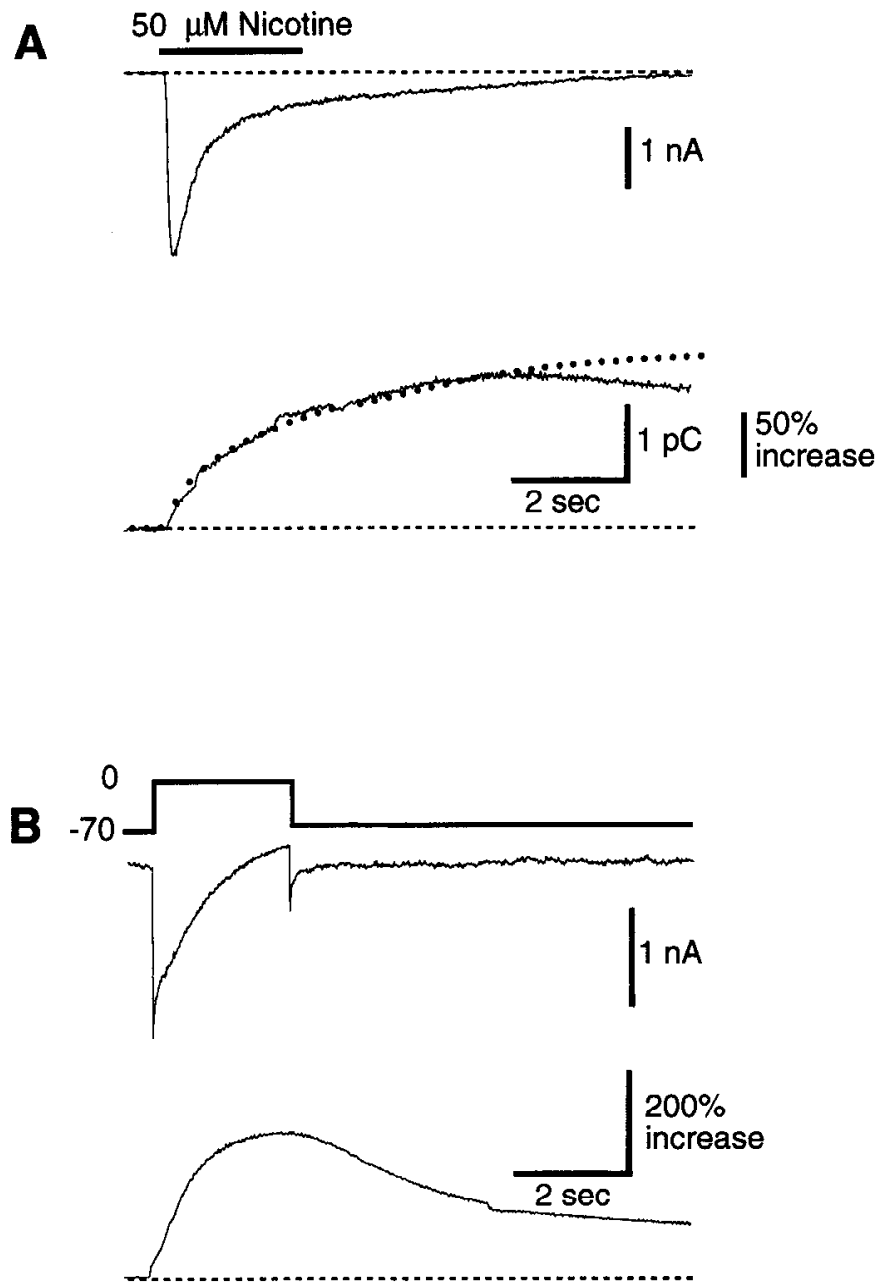

C

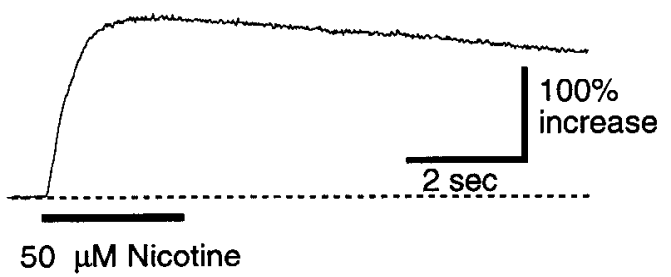

Figure 6. Comparison of nicotine-induced and voltage-induced fluorescence responses from voltage-clamped neurons. $A$, Current (top trace) and fluorescence (bottom trace) responses in real time of a neuron loaded with fluo-3 pentapotassium from the recording electrode (soln $\mathrm{C}$ ), and then challenged with $50 \mu \mathrm{M}$ nicotine (horizontal bar) while voltage clamping the cell at $-70 \mathrm{mV}$. The cumulative integral of the current in $\mathrm{pC}$ is shown as a function of time (dotted line) superimposed on the fluorescence response (solid trace) which it closely follows for at least 5 sec. $B, A$ voltage step from -70 to $0 \mathrm{mV}$ (top line) applied to the same neuron used for $A$ elicited a current (top trace) accompanied by a fluorescence response (bottom trace). $C$, Fluorescence response in real time from a different neuron in the same experiment loaded with fluo-3 AM and stimulated with $50 \mu \mathrm{M}$ nicotine without forming a patch seal or voltage clamping. In all cases the bath contained $10 \mathrm{~mm}$ calcium (soln $\mathrm{H}), 1 \mu \mathrm{M}$ TTX, and $50 \mathrm{~nm} \alpha \mathrm{Bgt}$.
The cadmium effect cannot be explained by an influx of cadmium quenching the fluor. The receptors do not appear to be very permeable to cadmium (see above). Moreover, direct fluorescence measurements on mixturcs of fluo-3 pentapotassium and cadmium both with and without EGTA buffering as previously described for other divalent cations (Minta et al., 1989) indicate that cadmium is at least as effective as calcium at inducing rather than quenching fluorescence and would have added to the signal had significant cadmium influx occurred (data not shown). The results indicate that most of the increase in intracellular calcium achieved by activation of either mAb 35AChRs or $\alpha$ Bgt-AChRs in unclamped neurons comes from calcium flux through VDCCs, presumably triggered by membrane depolarizations produced by currents through the receptors.

\section{Nicotine-induced calcium increases in voltage-clamped cells}

In view of the inferred contributions from VDCCs, it became important to determine whether activation of $\mathrm{mAb} 35-\mathrm{AChRs}$ produced any increase in intracellular calcium without the participation of voltage-gated channels. This was accomplishcd by measuring the nicotine-induced fluorescence in neurons voltage clamped below the threshold for activation of VDCCs.

The neurons were loaded with dye from the recording pipette which contained $50 \mu \mathrm{M}$ fluo-3 pentapotassium in the normal intracellular recording solution, and the membrane was voltage clamped at $-70 \mathrm{mV}$. Initial experiments were carried out with $10 \mathrm{~mm}$ calcium in the extracellular solution. The cell was allowed to fill about 2 min with dye and then responses were elicited by the application of $50 \mu \mathrm{M}$ nicotine from a puffer pipette. The integral of the nicotine-induced current (Fig. 6A, lower panel, dotted line) represents the total charge entering the cell and is proportional to the fluorescence response (Fig. 6A, lower panel, solid trace), as expected if calcium influx represents a constant fraction of the inward current and produces the fluorescence. The mean net peak fluorescence response from 30 clamped cells was $137 \pm 14 \%( \pm$ SEM) over basal levels. Rcducing the extracellular calcium concentration to $2 \mathrm{~mm}$ reduced the mean net peak fluorescence response to $66 \pm 10 \%$ (13 cells) over basal levels.

The same cells were also tested for VDCC-mediated fluorescence responses. After the cell recovered from the nicotinic response (fluorescence returned to basal levels), the holding potential of the cell was stepped from -70 to $0 \mathrm{mV}$ to activate VDCCs, and the accompanying fluorescence response was monitored (Fig. $6 B$ ). In the presence of $10 \mathrm{~mm}$ calcium the mean net peak fluorescence was $206 \pm 25 \%$ over basal levels ( 30 cells). This constituted a signal only half again as large as the nicotinic response. The dye is known to respond linearly with calcium concentrations up to $1 \mu \mathrm{M}$ (Minta et al., 1989), and varying the voltage step to manipulate the amplitude of the current confirmed that the fluorescence signal was proportional in a linear manner to the total charge entering the cell during the period of stimulation (data not shown). The results suggest that $\mathrm{mAb}$ 35-AChRs can elevate intracellular calcium concentrations at membrane potentials near rest almost as well as VDCCs do when activated by depolarization.

For comparison, cells from the same experiment were tested for nicotine-induced fluorescence without voltage clamp after loading with fluo-3 AM from the culture medium. In $10 \mathrm{~mm}$ calcium the mean net peak response was $156 \pm 20 \%$ (14 cells) over basal levels (Fig. $6 \mathrm{C}$ ), a value similar to that obtained for the voltage-clamped neurons. In $2 \mathrm{~mm}$ calcium the response 
was $146 \pm 15 \%$ ( $n=40$ cells $)$ over basal levels, somewhat larger than the value obtained with voltage-clamped neurons. It is difficult to make meaningful quantitative comparisons between the clamped and unclamped test conditions because of the differences in dye loading (and cell dialysis of clamped neurons) and because of differences in driving forces on the ions. In voltage-clamped cells the driving force on calcium through AChRs is much greater than in unclamped cells, where the depolarization of the membrane can approach the reversal potential of the receptors. This presumably accounts for the observation that cadmium blocks essentially all of the nicotineinduced fluorescence in unclamped neurons (implying it arises principally from VDCCs) while AChRs in clamped neurons can produce a fluorescence nearly as great without relying on VDCCs. Cadmium had no effect on the fluorescence signal per unit charge entering voltage-clamped cells when stimulated by nicotine $(0.26$ \pm 0.02 - vs $0.23 \pm 0.03$-fold increase in fluorescence per $\mathrm{nC}$, means \pm SEMs for 9 and 10 cells in the presence and absence of $0.2 \mathrm{~mm}$ cadmium, respectively).

The results demonstrate that in both 2 and $10 \mathrm{~mm}$ calcium, $\mathrm{mAb} 35-\mathrm{AChRs}$ can produce an increase in intracellular calcium that does not depend on voltage-gated calcium currents. The increases could, in principle, reflect contributions from two other sources in addition to calcium influx through AChRs. One of these is calcium release from internal stores, a possibility not examined in the present experiments. The other is calcium exchange driven by sodium influx (Blaustein and Hodgkin, 1969; Baker and McNaughton, 1978). To exclude contributions from this latter mechanism, voltage-clamp experiments were carried out in which extracellular sodium was replaced with an equivalent concentration of either cesium or lithium. The amplitude of nicotine-induced fluorescence changes in voltage-clamped cells loaded with fluo- 3 pentapotassium from the recording electrode was not diminished by the absence of external sodium $(0.20 \pm$ $0.04-, 0.24 \pm 0.14-$, and $0.16 \pm 0.04$-fold increase in fluorescence per $\mathrm{nC}$ for sodium, cesium, and lithium solutions, respectively; $3-8$ cells in each case). The results indicate that sodium/calcium exchange is unlikely to contribute significantly to the fluorescence signals produced by nicotine.

\section{Discussion}

The principal findings reported here are that synaptic-type AChRs on neurons have a substantial permeability to calcium and can elevate intracellular calcium levels. Under physiological conditions of low external calcium and a membrane potential free to depolarize, the $\mathrm{mAb} 35-\mathrm{AChRs}$ influence intracellular calcium levels largely by activating VDCCs. When the membrane potential is near rest, however, voltage clamp reveals that the receptors can elevate calcium levels independently from VDCCs, and that the calcium levels achieved can be substantial.

The GHK equation provided an estimate of at least $1: 1$ for the ratio of calcium to sodium permeabilitics of mAb 35-AChRs under the conditions tested. In this respect, the receptors have more in common with other classes of neuronal AChRs examined (Fieber and Adams, 1991; Mulle et al., 1992; Vernino et al., 1992) than with synaptic AChRs on vertebrate muscle cells (Adams et al., 1980; Decker and Dani, 1990). Neither voltage-gated currents nor receptor desensitization compromised the measurements. TTX and cadmium were used to block the voltage-dependent sodium and calcium currents, respectively, and potassium was absent from the recording solutions. Calcium-activated chloride currents were also unlikely to con- tribute significantly since few, if any, ciliary ganglion neurons of the age used here have such currents (Bader et al., 1987; Bernheim et al., 1989). Calcium-activated potassium currents (Dryer et al., 1991), if present despite the lack of potassium in the recording solution, would have shifted the reversal potential measurements in a direction that could only have led to underestimates of the calcium permeability. Residual leak currents were routinely subtracted from the nicotinic response. Receptor desensitization during the voltage ramp used to test the neurons was minimized by choosing an appropriate time window for examining the response. Reversing the ramp yielded the same values for the reversal potential, confirming that desensitization did not distort the determination.

The fact that $\mathrm{mAb}$ 35-AChRs can generate sizable currents when calcium is the only external cation confirms that the receptors permit calcium influx but has limited relevance for receptor properties under physiological conditions. Precedent exists for nonphysiological alterations in the divalent cation concentration (removal of extracellular calcium) changing the functional selectivity of an ion channel (Almers and McCleskey, 1984). The GHK analysis provides a relative calcium permeability for the receptors but the value is least reliable in low concentrations of calcium both because of the issues described previously and because of the inward rectification at positive membrane potentials, which makes the determination of the reversal potential less precise. These considerations made it important to determine independently whether activation of the receptors increased intracellular calcium levels under physiological conditions.

The fluorescent dye fluo-3 was used to monitor nicotine-induced calcium increases under physiological conditions because of its high sensitivity and ease of handling. Though the dye does not permit direct quantification of intracellular calcium concentrations, it does allow useful comparisons to be made. The fluorescence assay indicated that activation of $\mathrm{mAb} 35-\mathrm{AChRs}$, as well as $\alpha \mathrm{Bgt}$-AChRs, increases cytoplasmic calcium under physiological conditions. The blocking experiments with cadmium showed that most of the increase resulted from the receptors recruiting VDCCs. The ability of the receptors to depolarize the membrane to threshold for activation of VDCCs, then, may be their most salient feature for generating large, global increases in intracellular calcium. When the membrane potential is near rest, however, the calcium permeability of the receptors coupled with the driving force on calcium can produce substantial increases in intracellular calcium without VDCC participation. A recent study on rat sympathetic neurons using the calcium dye indo-1 found that activation of nicotinic receptors could elevate intracellular calcium levels at $-60 \mathrm{mV}$ by nearly 200 nм (Trouslard et al., 1993). As noted by Mulle et al. (1992), this provides a mechanism by which cell-cell interactions can regulate calcium-dependent events in a neuron without having to depolarize the ccll sufficiently to activate voltage-gated channels.

It is possible that not all of the calcium increase produced by nicotinic stimulation of voltage-clamped cells represents calcium influx through AChRs. The neurons have caffeine-sensitive calcium stores (Sorimachi, 1993), which may release calcium when cytoplasmic levels of the ion reach a sufficient level. The fact that the amplitude of the fluorescence signal in voltageclamped cells was proportional to the amount of nicotine-induced current over the first 6-7 sec, however, suggests that release from internal stores may not be a significant factor, at 
least during this time frame. Subsequent experiments will need to address the role of calcium stores in mediating or amplifying the effects of nicotinic signaling on intracellular calcium levels in neurons. The sodium substitution experiments rendered unlikely a significant contribution from sodium/calcium exchange (Blaustein and Hodgkin, 1969; Baker and McNaughton, 1978) in the nicotine-induced calcium increases seen in voltage-clamped cells.

Low-level activation of neuronal AChRs may also have important effects on calcium-dependent events by creating local high concentrations of calcium immediately beneath the plasma membrane. Local changes in calcium could activate calciumdependent currents or enzymes to regulate signaling and cellular processes in restricted domains in the cell. Microdomains of high calcium concentration are known to occur in presynaptic nerve terminals (Smith and Augustine, 1988; Llinas et al., 1992). In the present experiments, local changes in calcium concentrations would not have been resolved because the fluorescence signal was averaged over the whole cell and expressed as a percentage of basal fluorescence at rest.

If AChRs do mediate local calcium changes, mAb 35-AChRs and $\alpha$ Bgt-AChRs may have very different effects on calciumregulated events in the neurons. mAb 35-AChRs, as a consequence of their being highly concentrated in the postsynaptic membrane (Jacob et al., 1984; Loring and Zigmond, 1987), would likely have maximum effect on calcium-dependent events in the subsynaptic region. $\alpha \mathrm{Bgt}-\mathrm{AChRs}$, being diffusely distributed over the neuron surface (Jacob and Berg, 1983; Loring et al., 1985), could influence nonsynaptic and polydisperse components in the membrane. Future experiments will need to assess the impact of neuronal AChRs on local calcium concentrations underlying the plasma membrane.

\section{References}

Adams DJ, Dwyer TM, Hille B (1980) The permeability of endplate channels to monovalent and divalent metal cations. J Gen Physiol 75:493-510.

Almers W, McCleskey EW (1984) Non-selective conductance in calcium channels of frog muscle: calcium selectivity in a single-file pore. J Physiol (Lond) 353:585-608.

Bader CR, Bertrand D, Schlichter R (1987) Calcium-activated chloride current in cultured sensory and parasympathetic quail neurones. J Physiol (Lond) 394:125-148.

Baker PF, NcNaughton PA (1978) The influence of extracellular calcium binding on the calcium efflux from squid axons. J Physiol (Lond) 276:127-150.

Bernheim L, Bader CR, Bertrand D, Schlichter R (1989) Transient expression of a Ca${ }^{2+}$-activated $\mathrm{Cl}^{-}$current during development of quail sensory neurons. Dev Biol 136:129-139.

Bertrand D, Ballivet M, Rungger D (1990) Activation and blocking of neuronal nicotinic acetylcholine receptor reconstituted in Xenopus oocytes. Proc Natl Acad Sci USA 87:1993-1997.

Bertrand D, Galzi JL, Devillers-Thiery A, Bertrand S, Changeux JP (1993) Mutations at two distinct sites within the channel domain M2 alter calcium permeability of neuronal $\alpha 7$ nicotinic receptor. Proc Natl Acad Sci USA 90:6971-6975.

Blaustein MP, Hodgkin AL (1969) The effect of cyanide on the efflux of calcium from squid axons. J Physiol (Lond) 200:497-527.

Butler JN (1968) The thermodynamic activity of calcium ion in sodium chloride-calcium chloridc clcctrolytes. Biophys J 8:1426-1433.

Choi DW, Hoh J-y, Peters S (1988) Pharmacology of glutamate neurotoxicity in cortical cell culture: attenuation by NMDA antagonists. J Neurosci 8:185-196.

Cline HT, Constantine-Paton M (1989) NMDA receptor antagonists disrupt the retinotectal topographic map. Neuron 3:413-426.

Collingridge GL, Kehl SJ, McKlennan H (1983) Excitatory amino acids in synaptic transmission in the Schaffer collateral-commissural pathway of the rat hippocampus. J Physiol (Lond) 334:33-46.

Couturier S, Bertrand D, Matter J-M, Hernandez M-C, Bertrand S, Millar N, Valera S, Barkas T, Ballivet M (1990a) A neuronal nicotinic acetylcholine receptor subunit $(\alpha 7)$ is developmentally regulated and forms a homo-oligomeric channel blocked by $\alpha$-BTX. Neuron 5:847-856.

Couturier S, Erkman L, Valera S, Rungger D, Bertrand S, Boulter J, Ballivet M, Bertrand D (1990b) $\alpha 5, \alpha 3$, and non- $\alpha 3$ : three clustered avian genes encoding neuronal nicotinic acetylcholine receptor-related subunits. J Biol Chem 265:17560-17567.

Dani JA, Eisenman G (1987) Monovalent and divalent cation permeation in acetylcholine receptor channels. J Gen Physiol 89:959_ 983.

Decker ER, Dani JA (1990) Calcium permeability of the nicotinic acetylcholine receptor: the single-channel calcium influx is significant. J Neurosci 10:3413-3420.

Dryer SE, Dourado MM, Wisgirda ME (1991) Characteristics of multiple $\mathrm{Ca}^{2+}$-activated $\mathrm{K}^{+}$channels in acutely dissociated chick ciliaryganglion neurones. J Physiol (Lond) 443:601-627.

Fieber LA, Adams DJ (1991) Acetylcholine-evoked currents in cultured neurones dissociated from rat parasympathetic cardiac ganglia. J Physiol (Lond) 434:215-237.

Galzi J-L, Devillers-Thiery A, Hussy N, Bertrand S, Changeux J-P, Bertrand D (1992) Mutations in the channel domain of a neuronal nicotinic receptor convert ion selectivity from cationic to anionic. Nature 359:500-505.

Halvorsen SW, Berg DK (1987) Affinity labeling of neuronal acetylcholine receptor subunits with an $\alpha$-neurotoxin that blocks receptor function. J Neurosci 7:2547-2555.

Hamill OP, Marty A, Neher E, Sakmann B, Sigworth FJ (1981) Improved patch-clamp techniques for high-resolution current recordings from cells and cell-free membrane patches. Pfluegers Arch 391:85100 .

Ifune CK, Steinbach JH (1990) Rectification of acetylcholine-elicited currents in PC12 pheochromocytoma cells. Proc Natl Acad Sci USA 87:4794-4798.

Ifune CK, Steinbach JH (1992) Inward rectification of acetylcholineelicited currents in rat phaeochromocytoma cells. J Physiol (Lond) 457:143-165.

Jacob MH, Berg DK (1983) The ultrastructural localization of $\alpha$ - bungarotoxin binding sites in relation to synapses on chick ciliary ganglion neurons. J Neurosci 3:260-271.

Jacob MH, Berg DK, Lindstrom JM (1984) Shared antigenic determinant between the Electrophorus acetylcholine receptor and a synaptic component on chicken ciliary ganglion neurons. Proc Natl Acad Sci USA 81:3223-3227.

Lewis CA (1979) Ion-concentration dependence of the reversal potential and the single channel conductance of ion channels at the frog neuromuscular junction. J Physiol (Lond) 286:417-445.

Llinas R, Sugimore M, Silver RB (1992) Microdomains of high calcium concentration in a presynaptic terminal. Science $256: 766-769$.

Loring RH, Zigmond RE (1987) Ultrastructural distribution of ${ }^{125}$ Itoxin $\mathrm{F}$ binding sites on chick ciliary neurons: synaptic localization of a toxin that blocks ganglionic nicotinic receptors. J Neurosci 7:21532162 .

Loring RH, Chiappinelli VA, Zigmond RE, Cohen JB (1984) Characterization of a snake venom neurotoxin which blocks nicotinic transmission in the avian ciliary ganglion. Neuroscience 11:989-999.

Loring RH, Dahm LM, Zigmond RE (1985) Localization of $\alpha$-bungarotoxin binding sites in the ciliary ganglion of the embryonic chick: an autoradiographic study at the light and electron microscopic level. Neuroscience 14:645-660.

MacDermott AB, Mayer ML, Westbrook GL, Smith SJ, Barker JL (1986) NMDA-receptor activation increases cytoplasmic calcium concentration in cultured spinal cord neurones. Nature 321:519-522.

Malenka RC, Kauer JA, Zucker RS (1988) Postsynaptic calcium is sufficient for potentiation of hippocampal synaptic transmission. Science 242:81-84.

Margiotta JF, Gurantz D (1989) Changes in the number, function, and regulation of nicotinic acetylcholine receptors during neuronal development. Dev Biol 135:326-339.

Mathic A, Colquhoun D, Cull-Candy SG (1990) Rectification of currents activated by nicotinic acetylcholine receptors in rat sympathetic ganglion neurones. J Physiol (Lond) 427:625-655. 
Mayer ML, Westbrook GL (1987) Permeation and block of $N$-methylD-aspartic acid receptor channels by divalent cations in mouse cultured central neurones. J Physiol (Lond) 394:501-527.

Minta A, Kao JPY, Tsien RY (1989) Fluorescent indicators for cytosolic calcium based on rhodamine and fluorescein chromophores. J Biol Chem 264:8171-8178.

Mulle C, Choquet D, Korn H, Changeux J-P (1992) Calcium influx through nicotinic receptor in rat central neurons: its relevance to cellular regulation. Neuron 8:135-143.

Nishi R, Berg DK (1981) Two components from eye tissue that differentially stimulate growth and development of ciliary ganglion neurons in cell culture. J Neurosci 1:505-513.

Pugh PC, Berg DK (1994) Neuronal acetylcholine receptors that bind $\alpha$ - bungarotoxin mediate neurite retraction in a calcium-dependent manner. J Neurosci 14:889-896.

Ravdin PM, Berg DK (1979) Inhibition of neuronal acetylcholine sensitivity by $\alpha$-toxins from Bungarus multicinctus venom. Proc Natl Acad Sci USA 76:2072-2076.

Ravdin PM, Nitkin RM, Berg DK (1981) Internalization of $\alpha$-bungarotoxin on neurons induced by a neurotoxin that blocks neuronal acetylcholine sensitivity. J Neurosci 1:849-861.

Robinson RA, Stokes RH (1959) Electrolyte solutions. London: Butterworth.

Sands SB, Barish ME (1991) Calcium permeability of neuronal nicotinic acetylcholine receptor channels in PC12 cells. Brain Res 560: $38-42$.

Sands SB, Barish ME (1992) Neuronal nicotinic acetylcholine receptor currents in phaeochromocytoma ( $\mathrm{PC1} 2)$ cells: dual mechanisms of rectification. J Physiol (Lond) 447:467-487.

Sargent PB (1993) The diversity of neuronal nicotinic acetylcholine receptors. Annu Rev Neurosci 16:403-443.

Schneggenburger R, Zhou Z, Konnerth A, Neher E (1993) Fractional contribution of calcium to the cation current through glutamate receptor channels. Neuron 11:133-143.

Segal M, Manor D (1992) Confocal microscopic imaging of $\left[\mathrm{Ca}^{2+}\right]_{i}$ in cultured rat hippocampal neurones following exposure to $\mathrm{N}$-methylD-aspartate. J Physiol (Lond) 448:655-676.
Seguela P, Wadiche J, Dineley-Miller K, Dani JA, Patrick JW (1993) Molecular cloning, functional properties, and distribution of rat brain $\alpha 7$ : a nicotinic cation channel highly permeable to calcium. J Neurosci 13:596-604.

Smith SJ, Augustine GJ (1988) Calcium ions, active zones, and synaptic transmitter release. Trends Neurosci 11:458-464.

Sorimachi M (1993) Caffeine- and muscarinic receptor agonist-sensitive $\mathrm{Ca}^{2+}$ stores in chick ciliary ganglion cells. Brain Res 627:3440.

Thayer SA, Miller RJ (1990) Regulation of the intracellular free calcium concentration in single rat dorsal root ganglion neurons in vitro. J Physiol (Lond) 425:85-115.

Trouslard J, Marsh SJ, Brown DA (1993) Calcium entry through nicotinic receptor channels and calcium channels in cultured rat superior cervical ganglion cells. J Physiol (Lond) 468:53-71.

Vernallis AB, Conroy WG, Berg DK (1993) Neurons assemble acetylcholine receptors with as many as three kinds of subunits and can segregate subunits among receptor subtypes. Neuron 10:451-464.

Vernino S, Amador M, Luetje CW, Patrick J, Dani JA (1992) Calcium modulation and high calcium permeability of neuronal nicotinic acetylcholine receptors. Neuron 8:127-134.

Vijayaraghavan S, Pugh PC, Zhang Z-w, Rathouz MM, Berg DK (1992) Nicotinic receptors that bind $\alpha$-bungarotoxin on neurons raise intracellular free $\mathrm{Ca}^{2+}$. Neuron 8:353-362.

Yawo H (1989) Rectification of synaptic and acetylcholine currents in the mouse submandibular ganglion cells. J Physiol (Lond) 417: 307-322.

Yawo H, Mamiyama A (1993) Re-evaluation of calcium currents in pre- and post-synaptic neurones of the chick ciliary ganglion. J Physiol (Lond) 460:153-172.

Zhang ZW, Feltz P (1990) Nicotinic acetylcholine receptors in porcine hypophyseal intermediate lobe cells. J Physiol (Lond) 422:83-101.

Zhang ZW, Vijayaraghavan S, Berg DK (1994) Neuronal acetylcholine receptors that bind $\alpha$-bungarotoxin with high affinity function as ligand-gated ion channels. Neuron 12:167-177. 